\title{
PENYULUHAN TERKAIT CUCI TANGAN PAKAI SABUN DI TPA AL-IKHLAS POLRI JATISAMPURNA BEKASI
}

\author{
Septiani1), Intan Kurniawati Pramitaningrum¹), Muhammad Rizki Kurniawan') \\ 1)Program Studi Teknologi Laboratorium Medis, Fakultas Ilmu Kesehatan dan Teknologi, Universitas Binawan, Jakarta \\ Timur, DKI Jakarta, Indonesia \\ Corresponding author : Intan Kurniawati Pramitaningrum \\ E-mail : intan.kurniawati@binawan.ac.id
}

Diterima 04 Oktober 2021, Direvisi 26 Oktober 2021, Disetujui 26 Oktober 2021

\begin{abstract}
ABSTRAK
Kegiatan pengabdian kepada masyarakat berbasis penyuluhan ini dilakukan untuk mengetahui tingkat pengetahuan siswa melakukan kegiatan cuci tangan yang tepat sesusai dengan standar yang ditetapkan oleh WHO pada siswa TPA Al-Ikhlas Polri Jatisampurna Bekasi. Kesadaran dan pengetahuan terkait cuci tangan yang tepat dapat memproteksi diri dari berbagai penyakit terutama penyakit diare. Siswa sekolah TPA Al-Ikhlas Polri terdiri dari siswa pra sekolah dasar dan sekolah dasar usia 3-12 tahun yang berjumlah 21 orang. Pelaksanaan kegiatan diawali dengan metode kuisioner dan selanjutnya dilakukan dengan mensosialisasikan Perilaku Hidup Bersih dan Sehat (PHBS) terutama tentang perilaku cuci tangan yang tepat. Hasil pelaksanaan kegiatan PKM ini dari pretest yang dilakukan menunjukan bahwa $62 \%$ tidak mengetahui 6 gerakan cuci tangan dan $38 \%$ mengetahui 6 gerakan cuci tangan. Setelah dilakukan penyuluhan cuci tangan dan demo cuci tangan kepada siswa maka diperoleh hasil post test yaitu terjadi penurunan $19 \%$ tidak mengetahui 6 gerakan cuci tangan dan terjadi kenaikan menjadi $81 \%$ mengetahui 6 gerakan cuci tangan.
\end{abstract}

Kata kunci: cuci tangan; penyuluhan; kecacingan.

\begin{abstract}
This community service activity was carried out to determine the level of knowledge of students in carrying out proper hand washing activities according to the standards set by WHO in TPA Al-Ikhlas students at the Jatisampurna Polri, Bekasi. Awareness and knowledge related to proper hand washing can protect themselves from various diseases, especially diarrheal diseases. TPA Al-lkhlas Polri students consist of pre-primary and elementary school students aged 3-12 years, totaling 21 people. The implementation of the activity begins with the questionnaire method and is then carried out by socializing the Clean and Healthy Life Behavior), especially regarding proper hand washing behavior. The results of the implementation of this community service from the pretest showed that $62 \%$ did not know the 6 hand washing movements and 38\% knew the 6 hand washing movements. After conducting hand washing counseling and hand washing demonstrations to students, the post test results were obtained, namely a decrease of $19 \%$ not knowing 6 hand washing movements and an increase to $81 \%$ knowing 6 hand washing movements.
\end{abstract}

Keywords: hand washing; counseling; worms.

\section{PENDAHULUAN}

Perilaku Hidup Bersih dan Sehat (PHBS) merupakan wujud yang nyata untuk meningkatkan kehidupan perorangan, keluarga dan masyarakat yang bertujuan untuk meningkatkan, memelihara dan melindungi kesehatannya masing-masing. Perilaku Hidup Bersih dan Sehat adalah semua perilaku kesehatan yang dilakukan atas kesadaran sehingga anggota keluarga atau keluarga dapat menolong dirinya sendiri di bidang kesehatan dan berperan aktif dalam kegiatan kesehatan di masyarakat (Kemenkes, 2011). Salah satu
PHBS adalah cuci tangan pakai sabun, praktik phbs perlu dilakukan dalam masyarakat untuk melakukan pencegahan penyakit. Penerapan PHBS harus diaplikasikan oleh semua pihak, baik dilingkungan pribadi, keluarga, sekolah, maupun masyarakat luas. Salah satu penyakit yang dapat ditimbulkan dari tidak menerapkan PHBS adalah diare dan kecacingan.

Kecacingan merupakan masalah kesehatan yang banyak ditemukan di dunia dan khususnya di Indonesia. Pada tahun 2018 terdapat 1,5 milyar orang atau $24 \%$ penduduk dunia terserang kecacingan. Menurut data WHO, $53 \%$ kejadian kecacingan terjadi pada 
usia anak (Jourdan et al., 2018). Penelitian yang dilakukan pada 124 anak sekolah dasar di Padang tahun 2017, menujukkan 53,2\% positif kecacinganyang disebabkan karena mengenai kebersihan kuku tangan(Suriani et al., 2020). Pada penelitian lain dengan responden anak sekolah dasar di Kabupaten Bima menyebutkan bahwa salah satu faktor risiko kecacingan yaitu kebiasaan mencuci tangan yang tidak baik dengan prevalensi 73,6 \% (Syahrir \& Aswadi, 2016). Mencuci tangan merupakan salah satu upaya menjaga kebersihan jari tangan dan kuku. Mencuci tangan dengan menggunakan sabun dianggap efektif sebagai bentuk pencegahan penyakit. Hal ini sejalan dengan kajian yang dilakukan oleh (Rosyidah et al., 2019) yang memperlihatkan bahwa terdapat hubungan antara perilaku mencuci tangan dengan kejadian diare.

Menurut penelitian sebelumnya di Langsa Barat menunjukkan bahwa perilaku mencuci tangan dengan menggunakan air bersih dan sabun memiliki pengaruh signifikan terhadap kecacingan pada balita (Yusrianti, 2017). Pada penelitian kejadian diare tahun 2019 di salah satu sekolah dasar di Ciputat menyebutkan bahwa terdapat hubungan antara perilaku mencuci tangan dengan kejadian diare (Rosyidah et al., 2019). Pada penelitian mengenai hubungan pengetahuan dan sikap terhadap perilaku cuci tangan di Kelurahan Pegirian, Surabaya menunjukkan bahwa $70,2 \%$ responden memiliki kurang pengetahuan mengenai perilaku cuci tangan. Dari hasil penelitian tersebut menunjukkan responden belum banyak yang mengetahui langkah cuci tangan yang benar. Hasil penelitian juga menunjukkan bahwa pengetahuan mengenai cuci tangan belum diterapkan dalam kehidupan sehari-hari (Octa, 2019).

Perkembangan inovasi dalam bidang kesehatan terus meningkat, hal ini bisa dilihat dari peralihan pola mencuci tangan konvensional yang diganti dengan penggunaan hand sanitizer. Berdasarkan penelitian mengenai efektivitas mencuci tangan dengan hand sanitizer menunjukkan bahwa angka kuman dengan cuci tangan dengan sabun adalah 3,5 CFU $/ \mathrm{cm}^{2}$ dan dengan hand sanitizer adalah 8,17 CFU $/ \mathrm{cm}^{2}$ (Djannah Fajar Ardi, 2013). Mencuci tangan dengan air dan sabun dianggap dapat menyingkirkan kotoran dan mengangkat lapisan lemak. Penggunaan hand sanitizer juga dianggap baik karena mengandung alkohol yang bersifat bakterisidal dan mampu menghancurkan membran bakteri (desiyanto \& Djannah, 2013).

$$
\text { Kegiatan Pengabdian kepada }
$$

Masyarakat (PKM) ini dilakukan di Taman
Pendidikan Al Quran (TPA) Al-lkhlas Polri yang berlokasi di Jatisampurna Bekasi. Siswa sekolah TPA Al-Ikhlas Polri terdiri dari siswa pra sekolah dasar dan sekolah dasar usia 3-12 tahun yang terdiri dari 11 orang siswa laki-laki dan 10 orang siswa perempuan. Rentang usia tersebut memiliki kecenderungan bermain, salah satunya adalah bermain tanah. TPA AlIkhlas Polri memiliki siswa yang masih belum dibekali dengan pengetahuan mencuci tangan.

Permasalahan yang diperoleh berdasarkan hasil survey awal dan wawancara dengan kepala sekolah Taman Pendidikan Al Quran (TPA) Al-Ikhlas Polri diketahui bahwa sebagian besar siswa masih belum dibekali dengan pengetahuan mencuci tangan pakai sabun. Melalui kegiatan Pengabdian Kepada Masyarakat ini diharapkan dapat meningkatkan pengetahuan siswa mengenai cara mencuci tangan yang baik dan mendapat informasi mengenai cara mencuci tangan pakai sabun. Kegiatan akan dilakukan melalui penyuluhan.

\section{METODE}

Metode pelaksanaan penyuluhan terkait cuci tangan pakai sabun dengan cara sosialisasi materi mengenai cuci tangan pakai sabun. Mitra dari kegiatan penyuluhan ini adalah siswa dan guru pendamping. Adapun tahapan penyuluhan terkait cuci tangan pakai sabun antara lain :

1. Tahap Identifikasi Masalah

Kegiatan ini dilakukan dengan wawancara kepada kepala sekolah TPA Al-Ikhlas Polri terkait permohonan ijin untuk memfasilitasi proses pengabdian masyarakat, penentuan peserta serta waktu dan tempat pelaksanaan pelatihan.

2. Tahap Penyuluhan

Tahap pelaksanaan penyuluhan dilaksanakan pada hari Minggu, 23 Mei 2021 di TPA Al-Ikhlas Polri diikuti oleh sebanyak 21 siswa. Kegiatan ini dilaksanakan secara tatap muka dengan tetap memenuhi protokol kesehatan yaitu membersihkan area sebelum kegiatan, menggunakan masker, peserta yang hadir mencuci tangan sebelum memasuki ruangan, duduk berjarak dan tidak membuka masker selama acara berlangsung. Kegiatan diawali dengan sambutan dari kepala sekolah, kemudian siswa dan pendamping mengisi kuisioner pretest dan posttest terkait dengan bagaimana cara siswa memahami langkahlangkah cuci tangan sebelum dan sesudah mendengarkan isi materi penyuluhan, dan yang terakhir adalah melakukan praktik cuci tangan dengan sabun. 
3. Tahap Evaluasi

Kegiatan ini dilakukan dengan mengevaluasi seluruh kegiatan sehingga dapat diketahui hasil yang diperoleh selama kegiatan berlangsung, terutama jika mengalami permasalahan/kendala, serta memberikan solusi dalam bentuk laporan akhir kegiatan pengabdian kepada masyarakat.

\section{HASIL DAN PEMBAHASAN}

\section{Tahap identifikasi}

Hasil dari identifikasi permasalahan yang didapatkan dari hasil wawancara dengan pihak kepala sekolah TPA Al-lkhlasTPA AlIkhlas Polri menggambarkan bahwa siswa yang masih belum dibekali dengan pengetahuan mencuci tangan. Kebiasaan cuci tangan yang dilakukan oleh para siswa hanya menggunakan air mengalir saja tanpa sabun. Maka dilakukan kegiatan penyuluhan mengenai 6 langkah cuci tangan menggunakan sabun serta mempraktekan langsung bagaimana cara mencuci tangan pakai sabun dengan baik dan benar.

\section{Tahap Penyuluhan}

Kegiatan pelatihan ini dilakukan dengan metode mengisi kuisioner pretest pemahaman siswa mengenai cara cuci tangan pada tanggal yang telah direncanakan yaitu Minggu, 23 Mei 2021 pukul 13.00-15.00 WIB di TPA Al-Ikhlas Polri diikuti oleh sebanyak 21 siswa.. Berikut gambar grafik hasil pretest pemahaman siswa terkait 6 langkah gerakan cuci tangan:

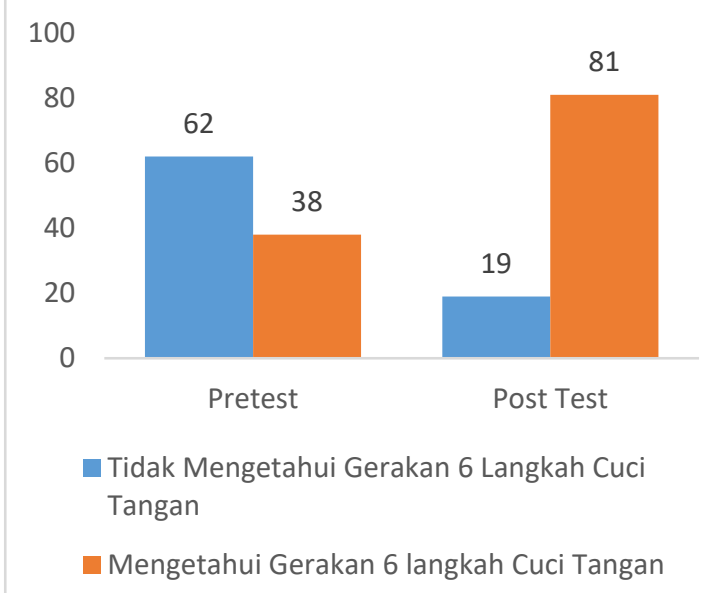

Gambar 1. Grafik hasil pretest dan post test pemahaman siswa

Berdasarkan hasil pretest Siswa TPA Al-lkhlas Polri pada (Gambar 1) memperlihatkan bahwa sebagian besar siswa belum memahami gerakan 6 langkah cuci tangan yaitu sebanyak 62\% (13 siswa) sedangkan 38\% (8 siswa) sudah memahami 6 langkah gerakan cuci tangan.

Hasil penilainan tersebut ditindaklanjuti melalui penyuluhan dengan menyampaikan materi mengenai cara mencuci tangan yang benar dijelaskan 6 langkah gerakan mencuci tangan dengan sabun yang benar yaitu: 1 . Menggosok kedua telapak tangan, 2. Menggosok punggung dan sela-sela jari tangan kiri dan tangan kanan, 3. Menggosok kedua telapak tangan dengan sela-sela jari, 4. Mengunci jari kedua tangan, 5. Menggosok ibu jari, dan 6. Menggosok dan memutar ujung jari tangan kanan di telapak tangan kiri dan sebaliknya (Gambar 2).

Penyuluhan diberikan dalam bentuk interaktif disesuaikan dengan usia siswa, demo cuci tangan dan memberikan poster berisikan langkah cuci tangan. Kegiatan penyuluhan cuci tangan dan demo cuci tangan pakai sabun dapat dilihat pada Gambar 3.

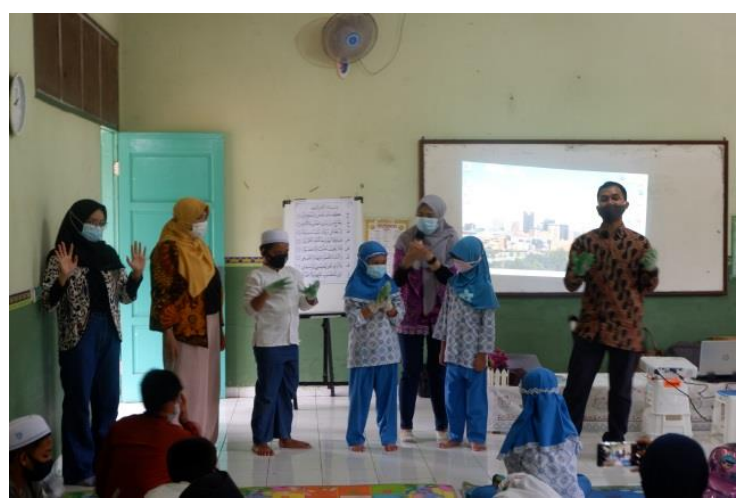

Gambar 2. Demo 6 langkah gerakan mencuci tangan dengan sabun yang benar

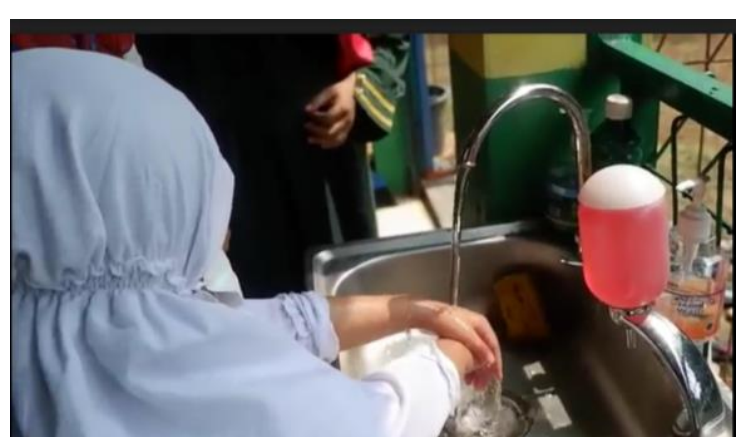

Gambar 3. Demo cuci tangan pakai sabun

Kegiatan penyuluhan ini bertujuan untuk meningkatkan pemahaman siswa terkait cuci tangan pakai sabun, berdasarkan hasil posttest setelah penyampaian materi, pemahaman siswa mengalami peningkatan sesuai dengan yang diharapkan

Berdasarkan Gambar 1 diperoleh bahwa terdapat $81 \%$ (17 siswa) dari 21 siswa sudah memahami gerakan 6 langkah cuci tangan dan sisanya $19 \%$ dari siswa belum mengetahui gerakan 6 langkah cuci tangan. Hal ini 
memperlihatkan bahwa kegiatan penyuluhan terkait cuci tangan pakai sabun untuk meningkatkan pemahaman siswa telah direncanakan dan dipersiapkan dengan sangat baik oleh tim pengabdian.

\section{Tahap Evaluasi}

Tahap terakhir dari kegiatan pelatihan ini adalah evaluasi kegiatan dan rencana tindak lanjut. Respon positif dan antusias dari kepala sekolah TPA Al-lkhlas sangat baik, pelaksanaan penyuluhan dan interaksi dengan para siswa berjalan lancar. Tindak lanjut yang dapat dilakukan tim pengabdian kepada masyarakat adalah melakukan pemeriksaan kulit, melakukan pemeriksaan kecacingan kepada siswa dan melakukan penyuluhan lain yang berkaitan dengan masalah kesehatan.

\section{SIMPULAN DAN SARAN Simpulan}

Berdasarkan hasil dan pembahasan yang telah diuraikan dapat disimpulkan bahwa tingkat pemahaman siswa dalam memahami dan mempraktekan gerakan 6 langkah cuci tangan yang ditetapkan oleh WHO cukup efektif dan mengalami peningkatan setelah dilakukan penyuluhan dari $38 \%$ menjadi $81 \%$. Timbulnya kesadaran dalam diri siswa diharapkan mampu memproteksi diri dari berbagai macam penyakit.

\section{Saran}

Perlu dilakukan selalu pendampingan dan evaluasi terhadap para siswa agar terbiasa dengan mencuci tangan dengan sabun secara baik dan benar.

\section{UCAPAN TERIMAKASIH}

Terimakasih TPA Al-lkhlas yang sudah membantu menyukseskan kegiatan penyuluhan ini, dan terima kasih kepada LPPM dan Universitas Binawan yang sudah mendanai acara kegiatan ini.

\section{DAFTAR RUJUKAN}

Djannah Fajar Ardi, S. N. D. (2013). Efektivitas Mencuci Tangan Menggunakan Cairan Pembersih Tangan Antiseptik (Hand Sanitizer) Terhadap Jumlah Angka Kuman. Jurnal Kesehatan Masyarakat (Journal of Public Health), Vol 7, No 2 (2013): Jurnal Kes Mas FKM UAD September 2013.

Jourdan, P. M., Lamberton, P. H. L., Fenwick, A., \& Addiss, D. G. (2018). Soiltransmitted helminth infections. The Lancet, 391(10117), 252-265. https://doi.org/10.1016/S0140-

6736(17)31930-X
Kemenkes. (2011). Peraturan Menteri Kesehatan Republik Indonesia. Peraturan Menteri Kesehatan No. 2406 TAHUN 2011 Tentang Pedoman Umum Penggunaan Antibiotik, 1-69.

Octa, A. (2019). Hubungan Pengetahuan Dan Sikap Terhadap Perilaku Cuci Tangan Pada Masyarakat Kelurahan Pegirian. Jurnal PROMKES, 7(1), 1. https://doi.org/10.20473/jpk.v7.i1.2019.111

Rosyidah, A. N., Studi, P., Keperawatan, I., Islam, U., Syarif, N., Tangan, C., \& Diare, K. (2019). Hubungan Perilaku Cuci Tangan terhadap Kejadian Diare pada Siswa Sekolah Dasar Negeri Ciputat 2. 3(1), 10-15.

Suriani, E., Irawati, N., \& Lestari, Y. (2020). Analisis Faktor Penyebab Kejadian Kecacingan pada Anak Sekolah Dasar di Wilayah Kerja Puskesmas Lubuk Buaya Padang Tahun 2017. Jurnal Kesehatan Andalas, $8(4)$, 81-88. https://doi.org/10.25077/jka.v8i4.1121

Syahrir, S., \& Aswadi. (2016). Faktor yang Berhubungan dengan Kejadian Kecacingan pada Siswa SDN Inpres no. 1 Wora Kecamatan Wera Kabupaten Bima. Higiene, 2(1), 41-48.

Yusrianti, sekolah tinggi ilmu kesehatan bustanul ulama langsa. (2017). Pengaruh PHBS dan Sanitasi Lingkungan terhadap Kecacingan pada Balita di Desa Kuala Langsa Kecamatan Langsa Barat. 3(1), 219-224. 